\title{
Assessment of phacoaspiration techniques in clear lens extraction for correction of high myopia
}

This article was published in the following Dove Press journal:

Clinical Ophthalmology

23 March 2010

Number of times this article has been viewed

\author{
Mostafa A El-Helw \\ Ahmed M Emarah \\ Department of Ophthalmology, \\ Cairo University, Egypt
}

Correspondence: Mostafa A El-Helw 52 Manyal Street, Cairo, Egypt Email helw@yahoo.com
Purpose: To evaluate various phacoaspiration techniques in clear lens extraction for the incidence of intraoperative difficulties and complications.

Patients and methods: This was a prospective study in which bilateral clear lens extraction was performed on 40 eyes of 20 patients, to correct high myopia. The patients were divided into 2 groups: group A underwent supracapsular phacoaspiration; group B were the contralateral eyes of the same patient. These patients were operated on with endocapsular phacoaspiration with the divide and conquer ( $\mathrm{D}$ and $\mathrm{C}$ ) technique. Preoperative ocular examination data were recorded and tested for significance. Intraoperative difficulties and complications such as nucleus cracking, capsule rupture and vitreous loss, and repeated chamber collapse were recorded. Postoperative examination data were recorded.

Results: Mean age was $35.65 \pm 5.85$ years. Mean follow-up time was $17.1 \pm 8.56$ months. In group A mean myopia was $-17.3 \pm 5.07$ diopters; in group B myopia was $-17.9 \pm$ 4.20 diopters. Mean preoperative uncorrected visual acuity (UCVA) was $0.04 \pm 0.0167$, while the mean postoperative UCVA was $0.435 \pm 0.1442$. There was a significant difference in preand postoperative BCVA within both groups, but not between the two groups. In both groups endothelial cell count (ECC) showed a significant difference between pre- and postoperative data; however, there was no statistically significant difference between both groups in postoperative ECC. The effective phacoaspiration time for group A was $4.6 \pm 1.6$ seconds, and for group B $9.90 \pm 2.27$ seconds $(P<0.005)$. No cases of capsule rupture occurred in group A, but 3 cases occurred in group B (15\%) (not significant, $P=0.231)$. Nucleus cracking did not occur in group A, but in group B 13 cases occurred (65\%). Chamber collapse occurred in 4 cases $(20 \%)$ in group A and 5 cases $(25 \%)$ in group $\mathrm{B}$ (not significant, $P=1.000$ ). Three cases of moderate postoperative iritis were recorded in group B in (15\%), in which posterior capsular rupture also occurred. No cases of iritis were recorded in group A (not significant, $P=0.231$ ). Two cases of cystoid macular edema were recorded in group B $(10 \%)$ and none in group A (not significant, $P=0.487$ ).

Conclusions: Supracapsular phacoaspiration for clear lens extraction in correction of high myopia seems to present no risk for the posterior capsule, although there is a marginal risk to the ECC.

Keywords: clear lens extraction, correction of high myopia, supracapsular phacoaspiration

\section{Introduction}

Clear lens extraction (CLE) to correct high myopia is a technique that is used in cases in which phakic intraocular lens (IOL) implantation is contraindicated. The risk of retinal detachment is a concern in this procedure. ${ }^{1-3}$ In order to decrease the intraocular complications related to posterior capsule rupture, and subsequent vitreous loss with increased incidence of retinal detachment (RD), ${ }^{4}$ supracapsular phacoaspiration 
is used. Supracapsular phacoaspiration is a 'capsule-friendly' technique in spite of its effect on the endothelial cell count (ECC). ${ }^{5}$ In our study we compared supracapsular and endocapsular phacoaspiration by the divide and conquer ( $\mathrm{D}$ and C) technique, the latter being less traumatic to ECC. ${ }^{6}$

\section{Patients and methods}

This was a nonrandomized prospective study that included 40 eyes of 20 patients who presented for the treatment of high myopia. Inclusion criteria were: myopia more than 10 diopters in both eyes, and patients not suitable for laser in situ keratomileusis (LASIK). The exclusion criteria were patients with previous history of RD, glaucoma, uveitis, ocular trauma, or previous ocular surgeries. Patient who were unfit for LASIK, but could not afford phakic IOLs, were allowed to enroll for this study. The patients were divided into 2 groups: group A underwent supracapsular phacoaspiration, and group $B$ was the contralateral eyes of the same patient. These patients were operated on with endocapsular phacoaspiration by the $\mathrm{D}$ and $\mathrm{C}$ technique.

Preoperative full ocular examination was conducted, including uncorrected visual acuity (UCVA) and best corrected visual acuity (BCVA), through slit lamp biomicroscopy of the anterior segment, dilated ocular examination to note the state of the lens, the vitreous, and a 3-mirror examination of the retinal periphery. Special note was taken of the vitreous. This was performed by allowing adequate dark adaptation of the examiner, off-axis slit beam and the use of a 3-mirror contact lens.

In cases where there was clinical evidence of posterior vitreous detachment, attempts were made to document this while performing the biometry, by switching to the B-mode of the ultrasonic machine and searching for a mobile thin membrane not attached to the optic nerve head which disappeared on increasing the gain. Patients that had flat tears or retinal thinning were treated with Argon laser and postponed. Patients with suspicious maculae underwent fluorscein angiography to exclude subretinal neovascular membrane.

Corneal topography was done in all cases. Preoperative specular microscopy using the noncontact specular microscope (NONCON ROBO-P, Konan Medical) was done and repeated 6 weeks postoperatively. IOL power was calculated according to the Sanders-Retzlaff-Kraff II formula (SRK II).

Patients underwent surgery under local peri-bulbar anesthesia and sedation. A standard 3-port phacoaspiration was performed with the clear cornea incision in the steepest meridian as determined by topography. In group A during the hydro-dissection step the lens matter was expressed into the anterior chamber and phacoaspiration was done in the supracapsular space, aided sometimes with pulses of phacorespiration to facilitate and accelerate the procedure. The settings used were (vacuum $300 \mathrm{mmHg}$, flow rate $22 \mathrm{~mm} / \mathrm{min}$, Phaco power $50 \%$ pulsed mode, and bottle height $80 \mathrm{~cm}$ ). In group $\mathrm{B}$ after hydro-dissection, endocapsular phacoaspiration was done using the $\mathrm{D}$ and $\mathrm{C}$ technique with the following settings: step 1: vacuum $70 \mathrm{mmHg}$, flow rate $22 \mathrm{~mm} / \mathrm{min}$, phacorespiration power $70 \%$ continuous mode, and bottle height $80 \mathrm{~cm}$; step 2: vacuum $250 \mathrm{mmHg}$, flow rate $22 \mathrm{~mm} / \mathrm{min}$, phacorespiration power $50 \%$ pulsed mode, and bottle height $80 \mathrm{~cm}$ ). Irrigation/aspiration (I/A) in both groups was done with the following settings (vacuum $400 \mathrm{mmHg}$, flow rate $25 \mathrm{~mm} / \mathrm{min}$ ). Implantation of foldable hydrophobic acrylic IOL with an overall diameter $13 \mathrm{~mm}$ were implanted in the capsular bag and in the ciliary sulcus in cases of posterior capsule rupture. Anterior vitrectomy was done in cases with ruptured capsule through the paracentesis incisions. There was an interval of 3 weeks between both eyes.

Intraoperative data included phacorespiration time, capsule rupture, nucleus cracking, and unstable anterior chamber with repeated collapse. Postoperative examination was done on days 1, 2, 3, 7, 14 and then after 6 weeks and every 3 months. Postoperative data including UCVA, BCVA, intraocular pressure (IOP), anterior chamber reaction, cystoid macular edema (CME), posterior capsule opacification (PCO), and retinal tears or detachment were recorded.

The results were analyzed using the SPSS computer software package, version 10.0 (Chicago, IL, USA). Continuous data were expressed as means with standard deviation. For comparison within and between the groups, the paired t-test and the Student's t-test were used, respectively. Qualitative data were summarized using frequencies and percentages. The two groups were compared using Fisher's exact test. All tests were two tailed and considered statistically significant at $P<0.05$.

\section{Results}

Mean age was $35.650 \pm 5.8515$ years; mean follow-up time is $17.1 \pm 8.564$ months. Mean myopia was $-17.3 \pm 5.069$ diopters in group A and $-17.9 \pm 4.204$ diopters in group B. Mean preoperative UCVA was $0.04+0.0167$, and mean postoperative UCVA was $0.435+0.1442$. Pre- and postoperative BCVA and ECC are given in Tables 1 and 2. There was a significant difference between pre- and postoperative BCVA within both groups (Table 1), but not between the two groups. 
Table I Pre- and postoperative best corrected visual acuity (BCVA)

\begin{tabular}{llll}
\hline & $\begin{array}{l}\text { Preoperative } \\
\text { BCVA }\end{array}$ & $\begin{array}{l}\text { Postoperative } \\
\text { BCVA }\end{array}$ & $P$ \\
\hline $\begin{array}{l}\text { Supracapsular } \\
\text { phacoaspiration }(\mathrm{n}=20)\end{array}$ & $0.375 \pm 0.102$ & $0.655 \pm 0.123$ & 0.000 \\
$\begin{array}{l}\text { Endocapsular } \\
\text { phacoaspiration }(\mathrm{n}=20)\end{array}$ & $0.380 \pm 0.009$ & $0.590 \pm 0.186$ & 0.000 \\
\hline
\end{tabular}

Within both groups pre- and postoperative ECC was differed significantly (Table 2), but postoperative ECC did not differ significantly between the two groups in (Table 3 ). Phacorespiration time for group A was $4.6 \pm 1.6$ seconds; for group B it was $9.90 \pm 2.27$ (significant, $P<0.000$ ) (Table 3 ). No cases of capsule rupture occurred group A, but 3 cases occurred in group B (15\%) (not significant between groups, $P=0.231)$. In group A no difficulty was experienced with nucleus cracking, as we did not need to crack the nucleus. In group B there were difficulties in nucleus cracking, as cheese-wiring occurred because the second instrument used to manipulate the nucleus was able to go through rather than crack the soft nucleus. This occurred in 13 cases $(65 \%)$. Chamber collapse occurred in 4 cases $(20 \%)$ in group A and in 5 cases $(25 \%)$ in group B (not significant, $P=1.000$ ). Moderate postoperative iritis was recorded in group B in the 3 cases $(15 \%)$ that had posterior capsular rupture. No cases of iritis were recorded in group A (not significant, $P=0.231$ ). CME was recorded in 2 cases in group B (10\%) and none in group A (not significant, $P=0.487$ ).

$\mathrm{RD}$ was not recorded in either group. Two eyes in group A and 3 eyes in group B underwent preoperative Argon laser treatment for flat tears but no cases underwent any further treatment postoperatively. Until exit from the study, we noted the occurrence of PCO at every follow-up visit. No cases of PCO that affected visual acuity were recorded in the sample studied.

\section{Discussion}

The main concern in highly myopic eyes undergoing CLE is $\mathrm{RD} .{ }^{1,7}$ The incidence of $\mathrm{RD}$ is related to rupture of posterior capsule and vitreous loss. ${ }^{8}$ No RD was seen in any of

Table 2 Pre- and postoperative endothelial cell count (ECC)

\begin{tabular}{llll}
\hline & $\begin{array}{l}\text { Preoperative } \\
\text { ECC }\end{array}$ & $\begin{array}{l}\text { Postoperative } \\
\text { ECC }\end{array}$ & $P$ \\
\hline $\begin{array}{l}\text { Supracapsular } \\
\text { phacoaspiration }(\mathrm{n}=20)\end{array}$ & $3212.8 \pm 307.98$ & $3080.1 \pm 326.01$ & 0.000 \\
$\begin{array}{l}\text { Endocapsular } \\
\text { phacoaspiration }(\mathrm{n}=20)\end{array}$ & $3220.25 \pm 270.84$ & $3065.50 \pm 262.62$ & 0.000 \\
\hline
\end{tabular}

Table 3 Postoperative best corrected visual acuity (BCVA), endothelial cell count (ECC) and phaco time

\begin{tabular}{llll}
\hline & $\begin{array}{l}\text { Supracapsular } \\
\text { phacoaspiration } \\
(\mathbf{n}=\mathbf{2 0})\end{array}$ & $\begin{array}{l}\text { Endocapsular } \\
\text { phacoaspiration } \\
(\mathbf{n}=\mathbf{2 0})\end{array}$ & $\mathbf{P}$ \\
\hline Postoperative BCVA & $0.655 \pm 0.123$ & $0.590 \pm 0.186$ & 0.201 \\
Postoperative ECC & $3080.1 \pm 326.01$ & $3065.50 \pm 262.62$ & 0.877 \\
Phacoaspiration time & $4.6 \pm 1.6$ & $9.90 \pm 2.27$ & 0.000 \\
\hline
\end{tabular}

our cases. This can be explained by: 1) the short follow-up period in our study (17.1 \pm 8.564 months), as the incidence of RD tends to occur at later stages; ${ }^{3} 2$ ) the meticulous preoperative selection, as all patients had a thorough 3-mirror examination of the retinal periphery; 3 ) the fact that none of the cases had an yttrium aluminium garnet (YAG) capsulotomy. It has been documented that RD incidence increases after YAG laser posterior capsulotomy. ${ }^{3,7}$ The combined effect of these three factors may contribute to the absence of RD cases in our study. The absence of cases of PCO in our series can again be attributed to the short follow-up period and also to the design of the IOL used in the study.

In our study we tried to compare efficacy and safety of supracapsular with that of endocapsular phacoaspiration. Supracapsular was more effective in our study, as manifested by the significant difference in phacoaspiration power that was used in both groups, which is in accordance with the results of Maloney et al. ${ }^{5}$ When we considered safety we evaluated two factors: ECC and posterior capsule integrity.

The endocapsular technique always poses less risk to the corneal endothelium in terms of ECC, ${ }^{5}$ but in our study there was no significant difference between the two groups. This can be explained by the fact that the patients were young with healthy endothelium, the lens matter was soft with a clear lens extraction, and the patients had high myopes and deep anterior chambers. Therefore, so in spite of performing the technique in a more anterior plane, we were still relatively far from the corneal endothelium compared to a more shallow anterior chamber in eyes with a lower axial length.

Anterior chamber stability may be lower in myopic eyes, because of a lower scleral rigidity, and the deeper anterior chamber necessitates tilting of the phacoaspiration probe, which places stress on the posterior lip of the phacoaspiration wound and may allow for wound leak. Also, intraocular fluidics are different in myopic eyes. An unstable anterior chamber in which the probe is further away from the posterior capsule would, logically, allow for a higher margin of safety. Chamber stability did not differ significantly between the two groups ( $20 \%$ and $25 \%$, respectively), yet all cases that 
had a ruptured posterior capsule also showed intraoperative chamber instability.

Integrity of the posterior capsule during the procedure did not differ significantly between the two techniques. However, the three cases of capsule rupture that occurred in the endocapsular group showed a relatively longer phacoaspiration time $(9,12,13$ seconds $)$. Also the proximity to the posterior capsule of the phacoaspiration tip may increase the incidence of posterior capsule injury. In the supra capsular group these two factors, which threaten the integrity of the posterior capsule, are greatly minimized because a shorter phacoaspiration time is more efficient. ${ }^{5}$ Also the phacoemulsification tip is further away from the posterior capsule.

\section{Conclusions}

Placing the phacoaspiration probe in a more anterior plane, in a relatively unstable environment, would allow for a higher margin of safety. Although such a position would be harmful to the corneal endothelium, this study showed that the risk to the corneal endothelium was did not differ significantly between both techniques, and even a marginal increase in the rate of ECC loss would be offset by the reduced occurrence of posterior capsule rupture with the more posterior placement of the phacoaspiration probe. Thus supracapsular phacoaspiration is a capsule-friendly technique. Although this comes at a cost to the corneal endothelium, the cost is marginal.

\section{Disclosures}

The authors declare no conflicts of interest.

\section{References}

1. Fritch CD. Risk of retinal detachment in myopic eyes after intraocular lens implantation: a 7-year study. J Cataract Refract Surg. 1998;24: $1357-1360$.

2. Colin J, Robinet A, Cochener B. Retinal detachment after clear lens extraction for high myopia: seven-year follow-up. Ophthalmology. 1999; 106:2281-2284

3. Fernandez-Vega L, Alfonso JF, Villacampa T. Clear lens extraction for the correction of high myopia. Ophthalmology. 2003;110: 2349-2354.

4. Jacobi FK, Hessemer V. Pseudophakic retinal detachment in High axial myopia. J Cataract Refract Surg. 1997;23:1095-1102.

5. Maloney WF, Dillman DM, Nichamin LD. Supracapsular phacoemulsification: a capsule-free posterior chamber approach. $J$ Cataract Refract Surg. 1997;23:323-328.

6. Kosrirukvongs P, Slade SG, Berkeley RG. Corneal endothelial changes after divide and conquer versus chip and flip phacoemulsification. J Cataract Refract Surg. 1997;23:1006-1012.

7. Ripandelli G, Scassa C, Parisi C, Gazzaniga D, D’ Amico D, Stripe M. Cataract surgery as a risk factor for retinal detachment in very high myopic eyes. Ophthalmology. 2003;110:2355-2361.

8. Colin J, Robinet A, Cochener B. Retinal detachment after clear lens extraction for high myopia: seven-year follow-up. Ophthalmology. 1999;106:2281-2284.
Clinical Ophthalmology

\section{Publish your work in this journal}

Clinical Ophthalmology is an international, peer-reviewed journal covering all subspecialties within ophthalmology. Key topics include: Optometry; Visual science; Pharmacology and drug therapy in eye diseases; Basic Sciences; Primary and Secondary eye care; Patient Safety and Quality of Care Improvements. This journal is indexed on

Submit your manuscript here: http://www.dovepress.com/clinical-ophthalmology-journal

\section{Dovepress}

PubMed Central and CAS, and is the official journal of The Society of Clinical Ophthalmology (SCO). The manuscript management system is completely online and includes a very quick and fair peer-review system, which is all easy to use. Visit http://www.dovepress.com/ testimonials.php to read real quotes from published authors. 